April 2019 Volume 2 No 2

\title{
Ruzpita (Azolla Pinnata Grass) As An Organic Fertilizer Of Nitrogen Binder (N2) In Increasing Plant Production Of Padi (Oryza Sativa)
}

\section{RUZPITA (Rumput Azolla Pinnata) SEBAGAI PUPUK ORGANIK PENGIKAT NITROGEN (N2) DALAM PENINGKATAN PRODUKSI TANAMAN PADi (Oryza sativa)}

\author{
Illham Anggit Prayoga ${ }^{1}$, Alvin Nugroho ${ }^{2}$, Andri Abdi ${ }^{3}$ \\ ${ }^{1,2}$ Program studi agribisnis, universitas muhammadiyah sumatera utara ${ }^{3}$ Program studi agroteknologi, \\ universitas muhammadiyah sumatera utara \\ Email: ilhamanggitprayoga@gmail.com, alvinnugroho1999@gmail.com, andriiabdy120200@gmail.com
}

\begin{abstract}
Azolla is one type of algae plant that can be used as organic fertilizer, especially for rice cultivation. Azolla can be used as an organic fertilizer that is able to meet nutrient requirements, especially $N$ for plants. Azolla's ability to provide $N$ for plants is because in Azolla there are Cyanobacteria which then both do symbiotic mutualism. The second symbiosis is then called Anabaena azollae. Anabaena azollae can fix N2 freely in the air so that it can contribute to the need for $N$ for plants in the soil.
\end{abstract}

Keywords: Azolla, Cyanobacteria, Anabaena azollae, pupuk N.

\begin{abstract}
Abstrak
Azolla merupakan salah satu jenis tanaman ganggang yang dapat digunakan sebagai pupuk organik khususnya untuk kegiatan budidaya tanaman padi. Azolla dapat digunakan sebagai pupuk organik yang mampu memenuhi kebutuhan hara terutama N bagi tanaman. Kemampuan Azolla menyediakan N bagi tanaman adalah karena pada Azolla terdapat Cyanobacteria yang kemudian keduanya melakukan simbiosis mutualisme. Simbiosis keduanya kemudian di namakan Anabaena azollae. Anabaena azollae dapat memfiksasi N2 bebas diudara sehingga dapat meyumbang kebutuhan $\mathrm{N}$ bagi tanaman didalam tanah.
\end{abstract}

Kata kunci: Azolla, Cyanobacteria, Anabaena azollae, N. pupuk

\section{A. PENDAHULUAN}

Padi (Oryza sativa L.) merupakan tanaman penghasil beras yang menjadimakanan pokok sebagian besar pendudukIndonesia. Permintaan beras semakin meningkat dari waktu ke waktu seiring dengan meningkatnya jumlah penduduk. Kesenjangan antara produksi dan konsumsi masih terjadi, sehingga perlu diatasi denganpeningkatan produksi beras.

Nitrogen $(\mathrm{N})$ merupakan unsur hara yang paling penting. Kebutuhan tanaman akan $\mathrm{N}$ lebih tinggi dibandingkan dengan unsur hara lainnya, selain itu $\mathrm{N}$ merupakan faktor pembatas bagi produktivitas tanaman. Kekurangan N akan menyebabkan tumbuhan tidak tumbuh secara optimum, sedangkan kelebihan $\mathrm{N}$ selain menghambat pertumbuhan tanaman juga akan menimbulkan pencemaran terhadap lingkungan. Nitrogen merupakan unsur hara yang paling banyak diperhatikan. Hal ini di sebabkan jumlah nitrogen yang terdapat di dalam tanah sedikit, sedangkan yang diangkut tanaman berupa panen setiap musim cukup banyak. Untuk memperoleh hasil padi yang baik difokuskan pada pengaturan waktu pemupukan nitrogen yang tepat, selama musim tanam.
Pada saat ini penggunaan pupuk anorganik oleh petani belum terlaksana secara baik karena penggunaan yang terlalu berlebihan.Penggunaan pupuk yang berlebihan, tidak efisien dan memiliki dampak negatif terhadap tanaman dan lingkungan.Untuk mengurangi efek negatif penggunaan pupuk anorganik tersebut perlu diiringi dengan pemberian pupuk organik. Salah satu jenis pupuk organik yang dapat digunakan adalah pupuk organik cair (POC). Pupuk organik cair merupakan pupuk organik dalam sediaan cair yang bermanfaatuntuk membantu menyediakan ketersediaan unsur hara bagi tanaman dan memperbaiki sifat fisik, biologi dan kimia tanah.

Pupuk organik merupakan solusi yang tepat untuk mensubtitusi pupuk anorganik. Pupuk organik dapat menggemburkan lapisan permukaan tanah, meningkatkan populasi jasad renik, mempertinggi daya serap dan daya simpan air pada tanah. Pupuk organik dapat dibedakan atas pupuk organik padat dan cair. Pupuk organik cair dapat secara cepat mengatasi kekurangan unsur hara. Pupuk organik cair umumnya 
tidak merusak tanah dan tanaman walaupun digunakan sesering mungkin.

Pupuk organik cair dapat berasal dari bahan - bahan organik seperti kotoran ternak, limbah padat pertanian, tumbuhan air dan lain sebagainya. Salah satu tumbuhan air yang dapat digunakan sebagai pupuk organik adalah Azolla (Azolla pinnata). Azolla merupakan jenis tumbuhan pakuan air yang hidup mengapung di lingkungan perairan dan mempunyai sebaran yang cukup luas serta mampu menambat N2 dari udara. Sebagai sumber hara nitrogen, Azolla dapat diberikan sebagai pupuk organik, dikomposkan ataupun sebagai pupuk hijau. Azolla telah banyak digunakan sebagai pupuk organik karena mengandung nitrogen yang cukup tinggi. Azolla banyak terdapat pada persawahan di Indonesia sehingga cukup menjanjikan untuk menjadikannya sebagai sumber nitrogen biologis yang berasal dari jasad hayati alami yang bersifat dapat diperbaharui. Pemberian Azolla yang berupa pupuk cair di pembibitan utama kelapa sawit diharapkan mampu menyediakan unsur hara yang mendukung pertumbuhan bibit.

Berdasarkan uraian diatas maka perlu diperhatikan persoalan unsur hara, dengan dilakukannya suatu upaya dengan menciptakan inovasi baru yang dapat membantu para petani padi untuk mengatasi permasalahan unsur hara serta mengurangi penggunaan pupuk kimia/urea. Sebuah inovasi baru diciptakan yang dapat membantu masyarakat dalam sektor pertanian yaitu berupa pupuk organik cair sebagai sumber nitrogen tanah dan tanaman berdasarkan tumbuhan alami rumput Azolla Pinnata yang diberi nama "POC-AZPITA SN" (Azolla Pinnata Sumber Nitrogen) yang bertujuan untuk membantu para petani padi menghasilkan kualitas padi yang baik dan keuntungan dari segi materialis

Rumput Azolla merupakan tanaman paku air yang termasuk ordo Salviniales, family Azollaceae (Surdina,2016). Azolla mempunyai beberapa spesies namun spesies yang banyak terdapat di indonesia adalah Azolla pinnata yang habitatnya berada di genangan air dan banyak tumbuh dilahan sawah. Kemampuan azolla selama hidupnya bersimbiosis mutualistis dengan ganggang hijau biru (Anabaena azollae) dapat mereduksi nitogen dari atmosfer menjadi amonia melalui enzim denitrogenase yang cukup efektif (Kuncarawati dkk,2005).

Pemberian azolla mengakibatkan
peningkatan pertumbuhan tanaman padi meningkatkan luas daun dan berat kering tanaman. Nitrogen yang cukup tersedia pade fase vegetatif menghasilkan jumlah anakan yang banyak dan luas daun yang lebih tinggi maka produk biomassa yang dihasilkan juga tinggi.

Kewirausahaan yang tim pelaksana ciptakan inovasi yang diberi nama "POC-AZPITA SN" sebuah produk pupuk organik cair yang sangat layak untuk di produksi dan dipasarkan, guna membantu masyarakat dalam mengatasi unsur hara serta pengurangan penggunan pupuk kimia/urea. Tidak sedikit pula para petani padi mendapatkan keuntungan yang rendah bahkan kerugian yang disebabkan kualitas padi yang buruk dan butir gabah yang sedikit."POC-AZPITA SN" pupuk organik cair berbahan baku rumput Azolla pinnata ini sebagai upaya dalam mengatasi permasalahan petani padi yang ramah lingkungan,harga terjangkau dan mudah dibuat serta hemat dalam segi materialis.

\section{B. METODE PENELITIAN}

Penelitian ini menggunakan metode eksperimen, dilaksanakan di lahan persawahan sampali. Kegiatan ini akan dilaksanakan sesuai jadwal yang ada dan di perlukan waktu selama 4 bulan.

Adapun bahan yang digunakan dalam penelitian ini adalah rumput azolla pinnata, urine kelinci, molase (tetes tebu), Em4, tuak bambu, air kelapa, air beras, masker, sarung, label dan botol.

Tahapan yang digunakan dalam penelitian ini adalah: pembuatan produk, pengujian produk, pengemasan dan pemasaran.

\section{PEMBAHASAN dan HASIL}

Tahapan pembuatan produk POC-AZPITA $\mathrm{SN}$ atau pelaksanaan produksinya dapat dilihat pada diagram berikut

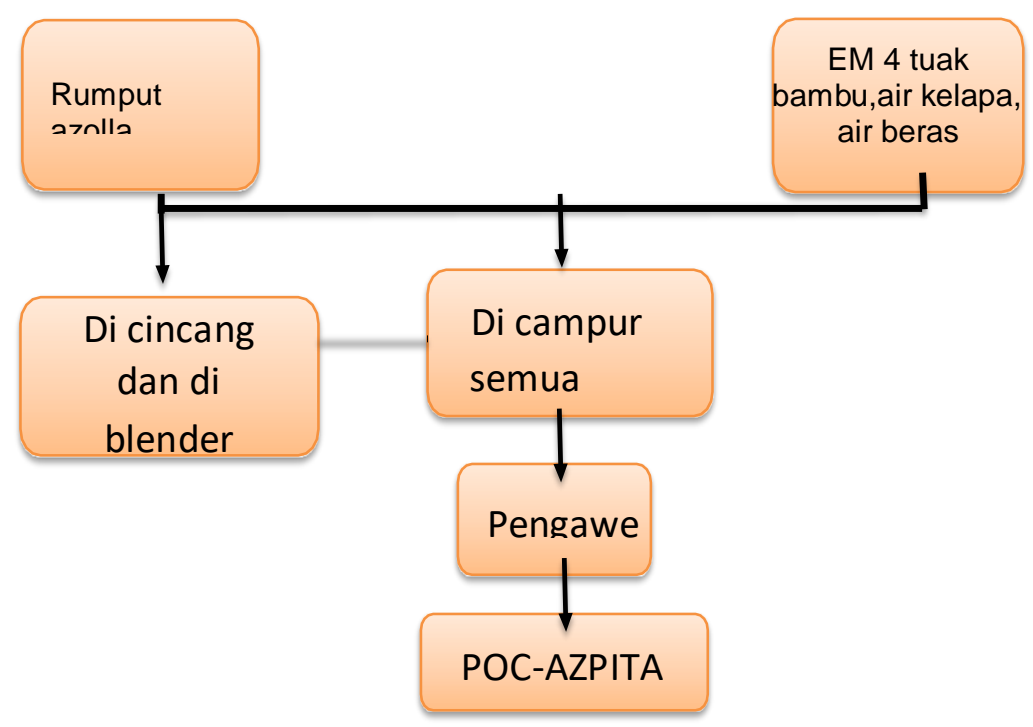

Gambar 1. Diagram Alur Tahap Pelaksanaan Pembuatan Produk

Selanjutnya pencapaian tujuan program bersangkutan dengan proses penjualan POC-AZPITA SN yang meliputi : 


\section{RUZPITA (Azolla Pinnata Grass) AS AN ORGANIC}

1) Pengemasan. Setelah produk POC-AZPITA SN dihasilkan, perlu penanganan agar produk terjual di pasaran, seperti pengemasan. Kemasan merupakan salah satu sumber daya tarik bagi konsumen untuk membeli produk. POC-AZPITA SN dikemas dalam botol yang dirancang khusus.

2) Pemasaran. Perencanaan yang akan dilakukan dalam mengenalkan produk dilakukan melalui metode iklan dan promosi penjualan. Bentuk iklan yang direncanakan adalah dengan cara menyebarkan brosur dan secara online. Setelah proses pemasaran selesai, tim pelaksana akan melakukan evaluasi usaha unutk melihat perkembangan pencapaian tujuan program yang dilaksanakan, untuk mengetahui kendala yang ada, cara menanganinya, mengontrol dan menganalisa sehingga program yg dilakukan bener-bener efektif dan maksimal. Evaluasi akan dilaksanakan setiap minggu dalam satu bulan.

Berikut ini hasil penelitian yang telah

dilakukan oleh kelompok.

\begin{tabular}{ccccccc}
\hline Produksi & Ke 1 & Ke 2 & Ke 3 & Ke 4 & Ke 5 & Ke 6 \\
\hline Botol & 60 & 75 & 88 & 90 & 95 & 92 \\
\hline \multicolumn{7}{c}{ Dalam 4 } \\
\hline
\end{tabular}

AZPITA SN yang menggunakan bahan baku rumput azolla pinnata $50 \mathrm{~kg}$, urine kelinci 30 liter, molase 10 liter, Em4 2 liter, tuak bambu 30 liter, air kelapa 25, air beras 25 liter untuk menghasilkan POC-AZPITA SN ukuran $500 \mathrm{ml}$ sekitar 500 botol.

Harga untuk satu botol adalah 19.230 sehingga akan diperoleh pendapatan kotor adalah sebesar 500 botol x $19.230,-=9.615 .000,-$.

Adapun keseluruhan modal yang akan dikeluarkan di awal pendirian usaha, meliputi sewa tempat, peralatan, bahan habis pakai, transportasi, promosi, dan lain-lain adalah Rp. 6.310.000,-. Jadi, jika dihitung berdasarkan keseluruhan modal awal yang meliputi bahan habis pakai, peralatan, dan biaya lain-lain sebesar Rp. 6.310.000,- maka modal akan kembali dalam waktu 2 minggu.

Analisis break event point (BEP) menunjukkan data sebagai berikut:

BEP $($ unit $)=$ FC $/(\mathrm{P}-\mathrm{VC})=3.280 .000 /(19.230$ 12.620) $=496$ unit

BEP $($ rupiah $)=$ FC $/(1-$ VC/P $)=$ Rp. 9.371.428,-

Berdasarkan BEP di atas maka BEP akan terpenuhi dalam waktu 1 minggu dan untuk produksi selanjutnya maka sudah mendapatkan keuntungan.

Dalam 1 bulan dapat menghasilkan 700 botol, dengan demikian dapat dihitung keuntungan yang diperoleh:

Keuntungan $=\pi=\mathrm{TR}-\mathrm{TC}$

$$
=13.461 .000-6.310 .000
$$

$$
=\text { Rp. 7.151.000,- / bulan }
$$

Dalam pelaksanaan kegiatan yang telah dilaksanakan untuk hasil yang didapat dalam 4 bulan, dalam bulan pertama peneliti telah mencari informasi. Survei petani cabai yang ada di Sumatera Utara, mulai untuk pembuatan desain dan juga mencari bahan baku. Untuk bulan selanjutnya peneliti mencoba untuk memproduksi AZPITAS-SN dalam satu minggu menghasilkan 700 botol.

Selanjutnya peneliti memulai untuk memasarkan produk kami dan mensosialisasikan langsung kepada petani dengan harga jual per/botol adalah Rp.19.230,- sehingga dari segi harga lebih murah dibandingkan dengan produk yang lainnya.

Azolla merupakan tumbuhan kecil yang mengapung di air terlihat berbentuk segitiga atau segiempat berukuran $2-4 \mathrm{~cm} \times 1 \mathrm{~cm}$ terdiri atas tiga bagian yaitu akar, rhizome dan daun yang terapung. Akar soliter menggantung di air, berbulu, panjang 1-5 $\mathrm{cm}$ dengan membentuk kelompok 3-6 rambut akar. Rhizome merupakan generasi sporofit, daun kecil, membentuk 2 barisan, menyirip bervariasi, duduk melekat, cuping dengan cuping dorsal berpegang di atas permukaan air dan cuping ventral mengapung. Daun berongga di dalamnya hidup Anabaena azollae. Azolla merupakan tumbuhan paku air dan salah satu pakan alami yang melimpah ketersediaannya di alam yang belum termanfaatkan secara optimal, tumbuh dan berkembang dengan cepat, hidupnya mengambang diatas permukaan air serta bersimbiosis dengan Cyanobacteria(alga hijau biru) mampu memfiksasi (N2) nitrogen udara. Azolla bisa dijadikan salah satu pakan alternatif bagi para pembudidayaikan yang cukup menguntungkan, biaya yang sangat ekonomis, dan juga sangat digemari oleh beberapa jenis ikan air tawar. Menurut penelitian Indarmawan et al. (2012) kandungan unsur hara yang terdapat dalam Azolla sp. yaitu N (1,96-5,30\%), P (0,16-1,59\%), Si (0,16$3,35 \%)$, Ca $(0,31-5,97 \%)$, Fe $(0,04-0,59 \%), \mathrm{Mg}(0,22-$ 0,66\%), Zn (26-989 ppm), Mn (66-2944 ppm).

Seiring dengan perkembangan ilmu pengetahuan, banyak penelitian yang menggali manfaat Azolla selain sebagai pupuk $\mathrm{N}$ alami. Azolla mempunyai peranan sebagai bioremediasi logam berat, limbah peternakan dan industri. Azolla diduga juga mempunyai peranan dalam bioremediasi senyawa aktif pestisida di lahan pertanian. Namun demikian, belum banyak informasi yang menjelaskan secara rinci tentang kemampuan Azolla dalam bioremediasi insektisida jenis buprofezin.

Azolla merupakan tumbuhan paku yang istimewa karena asosiasinya dengan ganggang hijaubiru Anabaena azollae menjadikannya mampu menambat nitrogen, sehingga kandungan protein azolla cukup tinggi, yaitu berkisar antara 13-30\% 
berat kering. Kandungan protein yang tinggi ini menjadikan azolla sebagai salah satu alternatif pakan ternak yang baik.

Azolla sangat mudah dibudidayakan dan sangat ideal sebagai pupuk hayati atau pupuk hijau pada tanaman di sawah. Permasalahannya adalah bahan organik tanah dan nitrogen sering kali terbatas jumlahnya, sehingga dibutuhkan sumber $\mathrm{N}$ alternative sebagai suplemen pupuk kimia (sintetis). Salah satu sumber $\mathrm{N}$ alternative yang cocok bagi tanaman di sawah yaitu Azolla. Dalam hal ini sangat sesuai dengan tanaman sejenis polong-polongan (legume) karena kemampuannya dalam mengikat N2-udara dengan bantuan bakteri Rhyzobium, yang menyebabkan kadar $\mathrm{N}$ dalam tanaman relative tinggi. Azolla merupakan sejenis paku air mini ukuran 3-4 cm yang bersimbiosis dengan Cyanobacteria pemfiksasi N yakni Anabaena azollae. Simbiosis ini menyebabkan azolla mempunyai kualitas nutrisi yang baik.

\section{KESIMPULAN}

Padi (Oryza sativa L.) merupakan tanaman penghasil beras yang menjadimakanan pokok sebagian besar pendudukIndonesia. Maka pupuk organic cair yang kami produksi sangat baik untuk produktivitas tanaman padi.

Adapun kesimpulan dalam kajian ini antara lain: 1) Mampu memenuhi kebutuhan unsur hara nitrogen pada tanaman; 2) produktivitas tanaman padi akan meningkat; 3) Menjaga kesuburan tanah; dan 4) Harga murah dibandingkan dengan produk lainnya.

\section{Daftar Pustaka}

Abu R.L.A., Z.Basri., Dan U.Made, 2017. Respon Pertumbuhan Dan Hasil Tanaman Padi (Oryza Sativa L.) Terhadap Kebutuhan Nitrogen Menggunakan Bagan Warna Daun. Jurnal Agroland 24 (2) : 119 - 127.

Daniarti H., M. Nurmilawati Dan Sulistiono. 2017. Pengaruh Dosis Dan Waktu Aplikasiazolla Pinnataterhadap Pertumbuhan Tanaman Kacang Tanah(Arachis Hypogaea(L.) Merr.). Jurnal Biologi \&Pembelajarannya, Vol.4, No.1. E-Issn: 2406 -8659

Habibullah.M., Idwar dan Murniati. 2015. Pengaruh Pupuk N, P, K Dan Pupuk Organik Cair (Poc) Terhadap Pertumbuhan, Hasil Dan Efisiensi Produksi Tanaman Padi Gogo (Oryza Sativa L.) Di Mediumtanah Ultisol. Jom Faperta Vol. 2 No. 2
Mamang.K.I., Iskandar Umarie dan Hudaini Hasbi.2017. Pengaplikasian Berbagai Macam Pupuk Azolla (Azolla Microphyla) Dan Interval Waktu Aplikasi Terhadap Pertumbuhan Dan Produksi Kedelai (Glycine Max (L) Merill). Jurnal Agritrop Volume 15 (1). Issn 1693-2877

Sudadi Dan Suryono. 2016. Pemanfaatan Azolla Sebagai Sumber Pakan Pada Budidaya Sistem Ganda Azolla-Lele. Journal Of Sustainable Agriculture, Vol. 31 No. 2. Hal. 114-117

Sudjana. B., 2014. Pengunaan Azolla Untuk Pertanian Berkelanjutan. Jurnal Ilmiah Solusi Vol. 1 No. 2

Surdina.E., Sayyid Afdhal El-Rahimi dan Iwan Hasri.2016. Pertumbuhan Azolla dengan Kombinasi Pupukkotoran Ternak. Urnal Ilmiah Mahasiswa Kelautan Dan Perikanan Unsyiah. Volume 1, Nomor 3: 298-306. Issn. 2527-6395

Suryati.D., Sampurno dan Edison Anom. 2015. Uji Beberapa Konsentrasi Pupuk Cair Azolla (Azolla Pinnata) Pada Pertumbuhan Bibit Kelapa Sawit (Elaeis Guineensis Jacq.) Di Pembibitan Utama. Jom Faperta Vol. 2 No. 1

Triadiati, Akbar Adjie Pratama Dan Sarlan Abdulrachman. 2012. Pertumbuhan Dan Efisiensi Penggunaan Nitrogen Pada Padi (Oryza Sativa L.) Dengan Pemberian Pupuk Urea Yang Berbeda. Buletin Anatomi Dan Fisiologi. Volume Xx, Nomor 2

Wijayanti.T., 2016. Dinamika Reduksi Insektisida Jenis Buprofezin Oleh Azolla Pinnata Pada Areal Persawahan Di Kecamatan Karangploso Kabupaten Malang. Jurnal Pena Sains Vol. 3, No. 2 E-Issn: 2527-7634 